\title{
Of Victims and Saviors: Government Rhetoric on OFWs on Death Row Abroad
}

\author{
Karen Y.Varona
}

Crisis communication is a strategy wherein governments (and other institutions) "feed" messages to media to persuade citizens they are taking action to keep crises under control (Baubion, 2013). Press statements and releases are among the most common forms of persuasive communication used to influence public discourse (Carbonero, 2013).

Spurred by the high-profile Mary Jane Veloso case in Indonesia in 2015, this study looks into Philippine government representation of cases of OFWs on death row abroad.

Results showed the persistence of the bagong bayani construction, with emphasis on personal choice and responsibility. That is, OFWs on death row were represented as victims of their own actions, thus constructing the cases as a migrant rather than a government responsibility. In contrast, the government was represented as an all-out and relentless savior, and strong it its policies.

Findings suggest the need for government to recognize these cases as part of the bigger human/drug trafficking problem-a government problem-as an initial step to a solution; and that media should be more critical in using press statements/releases and seek to broaden discourse by incorporating the views of migrants and advocates.

Keywords: crisis communication, government rhetoric, Mary Jane Veloso, OFWs on death row abroad, human/ drug trafficking

\section{Background}

The Philippine government started exporting labor as a temporary solution to its economic woes in the 70s. Four decades later, overseas labor migration not only plays a huge role in the country's economic policy but is deeply entrenched in Philippine society. Currently, an estimated 10\% of the Philippine population is living and working abroad, sending home remittances amounting to about $8-10 \%$ of the gross domestic product or GDP (Center for Migrant Advocacy [CMA], 2012; 2015 CFO Statistics on Philippine International Migration..

The country's elaborated labor migration framework has earned international recognition as a "best practices" model for origin countries. Despite regulatory mechanisms, however, overseas Filipino workers (OFWs) remain vulnerable to "exploitation, abuse, and discrimination" (International Organization for Migration [IOM] 2013, p. 2) in the highly profitable labor market. In the recent decade, migrant organizations have expressed concerns over the rising number of cases of OFWs in prisons abroad, especially those 
on death row for drug charges in China and Malaysia. Government records in 2013 show that there were 648 OFWs languishing in jails in the Asia Pacific, the Middle East and Africa, and the Americas and Europe (IOM 2013). As per 2015 figures, there were 92 OFWs on death row and 3,800 others in jail (Esmaquel II, 2016).

In 2008, former Senator Manuel Villar introduced a senate resolution appealing to Congress to conduct an urgent investigation into the "status of OFWs on death row with a focus on the assistance extended to them and the short-term and long-term policies adopted by the country" (Resolution urging an inquiry and assessment on the status of Filipinos on death row, 2008, p. 1); however, nothing seems to have come out of it.

A recent high-profile case was that of Mary Jane Veloso, who was granted reprieve only hours before her execution in Indonesia, on the condition that she testify against the organization involved in using her and other OFWs as drug couriers in Indonesia ("Mary Jane Veloso spared from execution," 2015). The incident prompted urgent calls from Gabriela, a women's party, for the government to conduct a thorough audit of OFWs with similar cases to disprove allegations of its negligence of OFWs in distress ("Gabriela pushes probe of DFA inaction into plight of Mary Jane, other jailed OFWs," 2015). Observers credit Veloso's reprieve to the efforts of the Philippinebased National Union of People's Lawyers, which has been appealing her case since her conviction in 2010 (Teodoro, 2015).

Media ethics scholar and former University of the Philippines professor Luis Teodoro criticized the government's inadequate and ad-hoc handling of such cases (Teodoro, 2015):

One would have expected the Philippine foreign serviceafter years and years of seeing OFWs hanged,decapitated or killed through some other method across the planet-to have developed by now those mechanisms of support that can make the difference between life and death. Too little and too late are the (self-) publicized efforts of the Aquino administration to save Veloso five long years after she was convicted. (para. 15)

Migrant advocates shared Teodoro's view. However, officials from the Department of Foreign Affairs (DFA) countered that the government has not at all been remiss in its duty and has already done much to protect OFWs, stressing that the troubles encountered by migrant workers abroad are beyond government control (CMA, 2012, p. 31). Since the Philippine government adopted labor migration as an economic strategy in the 70s, government objectives have largely defined migration discourse. While 
there was resistance early in the program, with people regarding those who left as traitors to the country, which was then under martial law this did not persist as the phenomenon became increasingly associated with labor migration (IOM, 2013, pp. 33-34).

Anchored on the notion of "migration as a sacrifice," the bagong bayani [modern hero] discourse was mainstreamed during the administration of Corazon Aquino. It was seen as a discursive strategy to justify the economic decision of continuing to send workers abroad for muchneeded remittances, despite the risks and struggles they faced in other countries. Key to the discourse was the articulation of labor migration as a heroic sacrifice Filipinos were making for their families and the role of the government as protector (Encinas-Franco, 2011). Analyzing government documents and news coverage of the controversial Maricris Sioson case in Japan and Flor Contemplacion case in Singapore, both in 1995, and the Angelo de la Cruz case in Saudi Arabia in 2004, Encinas-Franco found that discourse overrepresented overseas migrants as "'bodies'/'victims', 'entertainers'/'prostitutes', and 'domestic[s]"' (p.11). Moreover, research on the dela Cruz case showed that media coverage overwhelmingly focused on the event and the personalities involved-that is, episodic framingblaming OFWs in particular for putting their own lives at risk and praising the government as a hero for taking responsibility (Varona, 2010). These findings were not surprising considering that government sources dominated the coverage.

Ford and van Schendel (2012) observe that the bagong bayani discourse remains dominant, retaining the tendency towards "victimization and survival" resulting from high-profile cases such as the Sara Balabagan case in Saudi Arabia in the 1990s (p. 27). But alongside the dominant statesponsored discourse has been the migrant civil society representation of migration as "forced migration," that is, a migration of "necessity rather than a choice" (CMA, 2012, p. 57).

In the case of the Philippines, where decades of corruption, politicking, and pandering to elite interests have reduced majority of the population to poverty, overseas migration has become a necessity rather than a choice. The need is such that many take the chance to leave despite the dangers. This was the sentiment among OFWs in 2004 when the government imposed a travel ban on Iraq after the abduction of OFW Angelo dela Cruz: "Di na baleng mamatay sa Iraq na may trabaho kay sa mamatay na gutom sa Pilipinas" ["We would rather die having jobs in Iraq than die of hunger in the Philippines"] (Gorgonio, 2007, para. 9). More than a decade after, the same sentiment can be seen among applicants for domestic work to the soon-to-be opened Japanese market: "Kahit [delikado] yung lugar, basta 
me trabaho" ["It's okay if the place is dangerous as long as there's work"] ("24Oras: Katumbas ng halos P66,000, magiging buwanang sahod ng mga DH sa Japan," 2005).

Possibly to counter civil society discourse, government rhetoric in recent years has been reconstituting migrant sacrifice as "suffering that counts," willingly done with the promised reward of a better life for the family and the country (Piocos, 2015, page. 1), and, thus, a personal choice and responsibility. Overseas Workers Welfare Agency (OWWA) administrator Carmelita Dimzon stresses that migrants and their families "create [their own] vulnerabilities" when they accept payoffs from traffickers, take out huge loans to pay placement fees, and accept placement in dangerous places and circumstances (CMA, 2012, p.30). DFA officer Maynard Maleon suggested that migrants should be responsible for their own decisions: "They know they are being trafficked. They know they will not end up in Europe. You cannot stretch the argument to say that it's the government's fault because of poverty. OFWs and relatives should protect themselves" (p. 31).

However, concerned sectors observe that this viewpoint, based on classic economic theory, assumes that migrants make decisions based on "rational choice," when in actuality, they are not rational as they are often acts of sacrifice for the family (CMA, 2012, p. 25). In its development plan for 2011-2016, the government pledged to prioritize the generation of local employment such that overseas work would be "a choice rather than a necessity" and to guarantee the "welfare and protection" of those who would still opt to leave (p. 49). In truth, however, the government has remained dependent on overseas remittances and generally negligent and apathetic about the plight of migrants in distress, especially those on death row (Ibon Foundation, 2015; CMA, 2012).

While the government keeps touting the billions of dollars in overseas remittances, short of claiming them as an economic achievement, it seems to have overlooked that genuine development is rooted in upholding the rights and ensuring the "freedoms" of its people. Concerned groups stress that, instead of furthering migration, the government should address the root of the problem, which is the lack of decent and sustainable employment in the country (CMA, 2012, p. 57). As per the United Nations (UN) framework, development must be founded on the recognition of human rights, which also covers the provision of adequate food and housing, health, education, personal security, and privacy (Office of the United Nations High Commissioner, 2012, p. 5). It posits that a citizen living in poverty is deprived of several of these rights and emphasizes the responsibility of institutions to uphold and protect these rights. Similarly, for Nobel Award-winning economist Amartya Sen (1999), development, means the enhancement 
of life and freedoms, since when opportunities are present, people are able to forge their own path and assist others. Thus, development entails removing the key causes of "unfreedom," such as "economic unfreedom" (e.g. poverty), which make people vulnerable to other causes of unfreedom (political, social, etc.)

As it is, however, not only do Filipino migrants have to contend with all kinds of unfreedom at home; they also must face other sources of unfreedom in their search for a better life abroad. From the start of the process until they reach the country of destination, they are exposed to exploitation, abuses and discrimination, as well as hazards such as wars, natural disasters, and calamities (CMA, 2012, p. 26). Of particular concern in recent years has been the rising number of cases of Filipino migrants on death row abroad.

\section{Theoretical Framework}

In a country where virtually everyone is related to or knows an OFW, news of unfortunate incidents involving them abroad is apt to strike an emotional chord among citizens, which might escalate into a public outcry and prompt the government to take action to contain the crisis. For instance, the Contemplacion case pushed the Philippine government to reexamine friendly ties with Singapore and paved the way for the Migrant Workers Act of 1995 to be signed into law. More recently, public attention towards the languishing Veloso case in Indonesia resulted in a sudden and prominent display of government action aimed at assuring citizens that the government was on top of the situation and doing everything in its power to save the Filipina domestic. Crucial to this government strategy was communication.

Crisis communication refers to the process whereby an institution or organization-in this case the government-conveys messages about the state and impact of a crisis and the corresponding action it has taken (Baubion, 2013). The main goal is to "feed" these messages to media in order to persuade the people that the institution has the crisis under control ( $\mathrm{p}$. 20). Otherwise, it might be perceived as a negligent and ineffectual entity, which could "undermine" public trust and lead to a political crisis (p. 21).

Press statements and releases are among the most common forms of persuasive communication used by the government to influence public discourse (Carbonero, 2013). Press releases and statements employ indirect persuasion in that they masquerade as news when they are actually a form of advertisement (Igor, 2011). These news-like features include "pseudoquotations," "third person self-reference," bold and catchy headlines, and concise leads or opening paragraphs (Sleurs, Jacobs \& van Waes, 2002, p. 2). This preformulated format makes it more likely for press releases/statements 
to be incorporated into news articles or reports, with minimal alterations (Jacobs, 1999), a convenient recourse for harried reporters trying to beat deadlines. As a result, unsuspecting audiences are more receptive to the "news," unlike if they knew it was government propaganda.

This study is interested in how the Philippine government perpetuates representations of the labor migration phenomenon in times of crisis. Specifically, it examines official press statements and releases using Critical Discourse Analysis (CDA), an approach concerned with "dominance, discrimination, power and control" (Wodak, 2008, p.10), as they manifest in language to determine how the government constructs discourse on cases of OFWs on death row abroad in order to justify and legitimize its actions and pacify the nation. This study also uses discursive elements from both Teun van Djik (2000) and Gema Carbonero (2013) as applied to the labor migration context in the Philippines.

In his analysis of parliamentary debate in Europe, van Dijk (2000) affirmed the presence of racism in discourse, defining racism as a "social system of inequality" composed of "discriminatory actions" and "group dominance," and "racist ideologies" (p. 212). Moreover, an overview of discourses on immigration in Europe during crisis showed bias at every stage, such that "positive information about ingroups, [was] emphasized and negative information mitigated or ignored," while "negative information about [outgroups tended] to be emphasized and positive information ignored or mitigated" (Lirola, 2013, p. xvi - xvii).

Van Dijk (2000) identified several discursive structures commonly used in analyzing immigration debates in Europe, such as consensus, populism, and humanitarianism, although this study focuses only on those broad enough to be applicable to the Philippine context, namely, metaphors, number game, topoi and fallacies, among others. These elements were similarly used by Carbonero (2013) in her research on Spanish immigration discourse but which she categorized into argumentation strategies, namely, fallacies and topoi; and rhetorical style, namely, metaphors, hyperboles, repetitions, disclaimers.

\section{Significance of the Study}

An analysis of government representation of social issues is significant as this is the kind of framing that predominates in news media (Zarefsky, 2004). This is crucial since media framing influences how people see social problems, solutions, and whoever or whatever is responsible for them (Entman, 1993; Iyengar, 1990). According to Shanto Iyengar and Adam Simon (1993), studies have found that media tend to direct blame away from government when they present issues as a passing display of concrete or specific events (e.g., 
hostage taking event) or through episodic framing. Episodic framing tends to make audiences believe that the individuals involved should solve social problems, instead of the politicians and public institutions responsible for them. On the other hand, thematic framing presents issues within a broader context (e.g., political grievances of hostage takers), which tends to make audiences believe that politicians and public institutions should solve social problems.

A review of top news stories in leading Philippine broadsheets at any given day would reveal the predominance of official-that is, governmentsources, and thus, government framing. For instance, a content analysis of print media coverage of the capture of OFW Angelo dela Cruz by Iraqi resistance forces in 2004 revealed that government sources predominated and thus defined the framing of the case as a discrete, isolated incident and not as part of a much bigger migration problem (Varona, 2010). The media chastised OFWs for putting themselves at risk, demonized the Iraqi resistance forces, and elevated the Philippine and US governments into hero status (Varona, 2010). More than a decade later, in what Teodoro (2015) described as "tedious," and "predictable," media response to crisis involving OFWs convicted of drug trafficking abroad remains closely aligned with government response, and that is, to assign the blame on OFWs and to ignore context.

\section{Methodology}

This study focuses on argumentation and rhetorical elements as identified by van Djik (2000) and Carbonero (2013) and as categorized by Carbonero for examining how the government constructs discourse on overseas migrants on death row.

For argumentative structures, analysis is limited to topoi and fallacies. Topoi refer to "social beliefs ... which rely on norms and values only valid in certain contexts but are presented in a generalized way, as if they were irrefutable truths" (Carbonero, 2013, p. 264). Topoi are commonly used devices to rationalize "political inclusion or exclusion" (Wodak, 2008, p. 30). A widely used topoi in Europe is that of "immigration as a burden," thus suggesting that certain measures must be done to control it (Carbonero, 2013, p. 264).

Fallacies, on the other hand, are "violations of the rules for critical discussion" (van Eemereen \& Grootendorst, 1995, p. 224). They are arguments which appear logical, but which actually rely on sociological values-for instance, arguments which appeal to emotions or ad misericordiam (Carbonero, 2013) or those that appeal to authority or ad verecundiam (van Djik, 2000). 
Rhetorical structures refer to "conscious manifestations of language" which draw attention to or away from certain interpretations as intended by the speaker (Carbonero, 2013, p. 264). This study adopts elements from Carbonero (2013) and van Djik (2000), namely, metaphors (textual images), hyperbole (or number game), disclaimers (positive representations followed by a "but"), and repetitions.

For this study, analysis is limited to government press statements and releases on cases of OFWs on death row abroad which can be accessed from the official government website, The Official Gazette of the Republic of the Philippines at http://www.gov.ph/. "Press statements" refer to "reactionary statement[s] when an event takes place," while "press releases" refers to "news information, such as announcements or updates" ("Press Statements and Releases," 2012, para. 3).

\section{Results and Discussion}

A total of 25 press statements and releases on cases of OFWs on death row abroad from 2010 to 2015 were retrieved from the government's official website, including updates on the 2000 Rodelio Lanuza murder case in Saudi Arabia (two articles) and the Mary Jane Veloso case in Indonesia (eight articles). The most number of articles posted were in 2011 (13 articles) and 2015 (eight articles). The other years only had from two to zero articles.

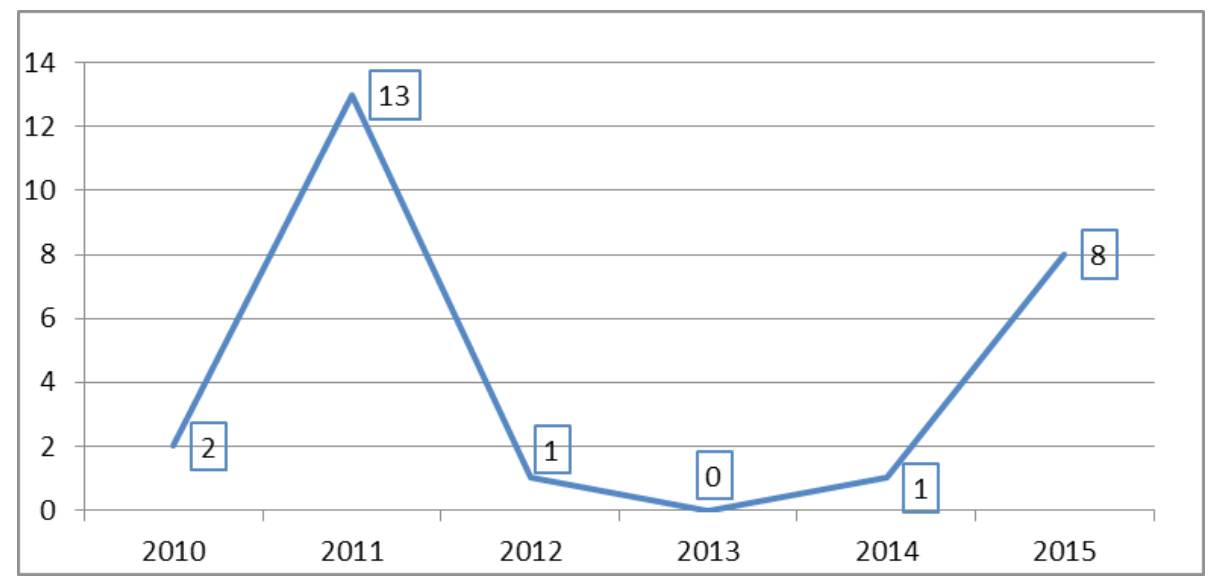

Fig. 1. Number of Press Statements/Releases on Overseas Filipino Migrants on Death Row, 2010-2015.

It is worth noting that the two sets of cases with the most number of statements or releases posted on the government website were those that received media and public attention. These were the cases of five OFWs convicted of drug smuggling in China in 2011, three of whom were later executed despite appeals for commutation from the Philippine government; 
and the Veloso drug trafficking case in Indonesia in 2015. Although one cannot discount the possibility of government negligence in posting press releases and statements online during the five-year period, the trend is still a cause for concern since the government has been observed to have a "very low" awareness of cases of OFWs on death row abroad and to "[twiddle] its thumbs" on cases that come to its attention unless forced into action by public clamor ("Gabriela pushes probe of DFA inaction into plight of Mary Jane, other jailed OFWs," 2015, para. 2-3). Thus, the negligible number of press releases and statements in 2010 (two articles), 2012 (one), 2013 (none) and 2014 (one) probably does not translate to the actual number of cases during this time. As of 2015, Gabriela estimates that there are some 88 cases - the same figure cited by the government, later corrected to 92 - of overseas migrants on death row in need of government action, recommending that an audit be done on these cases:

How many inmates have actually been given lawyers and interpreters? How many of these inmates have, like Mary Lane Veloso, clearly been duped into becoming drug mules? How many of these inmates [on] death row have been framed or merely acted in self defense? How many can still be saved? (para. 3)

At the core of all ideological representations is the demarcation between the ingroup and the outgroup, often manifested in the positive portrayal of the self and the negative portrayal of the other (van Djick, 2000, p. 12). Being evaluated as "less" in stature signifies negative treatment, marginalization, and exclusion (p. 40). In van Djick's words, "discrimination as unequal treatment can only be subjectively justified when dominant group actors believe that such treatment is normal or otherwise legitimate"(p. 40). In the case of labor migration discourse in the Philippines, the government takes the dominant position of the ingroup while overseas migrants are relegated to the outgroup.

Overall, government discourse discriminates against overseas migrants on death row by depicting them as victims of circumstances they brought upon themselves, in effect constructing the cases into a matter of personal choice and personal responsibility, rather than a social problem for governments to solve. Conversely, the government represented itself favorably in discourse as a savior going to great lengths to save erring migrants overseas.

To legitimize representations of overseas migrants on death row as victims through their own fault, the government relied on the "topoi of choice" or the assumption that OFWs on death row had a choice in what 
happened to them or were in control of circumstances that led to their incarceration. This could be seen in the litany of reminders and warnings from the government for them "not to be victimized" or to "[fall] prey" to drug syndicates, and to be "on guard," "vigilant "and "responsible":

- It appeals to all Filipinos not to be victimized by international drug syndicates. ("Death sentences," 2011, para. 12)

- [G]overnment would never tire in warning the people against being victimized by drug syndicates. ("Phl to remain," 2011, para. 2)

- He urged the Filipinos to heed the government's call to protect themselves against falling prey to international drug syndicates. ("Malacanang warns," 2012)

- Our people must take full responsibility for their actions by always being on guard against inducements. ("Death sentences," 2011, para. 12)

- Filipino travelers should remain vigilant and responsible in verifying invitations to work abroad. ("Filipina convicted," 2011, para. 6)

The discourse deemphasized the role of the government in crafting policies and enforcing laws to protect OFWs from unscrupulous recruiters and from drug traffickers and syndicates. Instead, it placed the burden of navigating these hazards on OFWs.

"Topoi of choice" was also used to suggest that OFWs on death row deserved to be there for breaking the law. This could be seen in the reminders for OFWs not to disobey the law and in the reminders and bold statements on the strict laws and harsh penalties in other countries. In addition, the lack of details on the reason or the circumstances behind the crime in most press messages and releases further pointed to the assumption of guilt:

- [W]e appeal to our nationals overseas to observe the local laws of their host countries, and to avoid involvement in criminal activities. ("Statement of the Department...Carlito Lana," 2014, para.9)

- Under Chinese criminal law, a person caught in possession of more than 50 grams of illegal drugs could be sentenced to death, if convicted. ("Death sentence of 2," 2011, para. 4)

- Nene was apprehended together with [her] common-law [partner] in a raid conducted by the Saudi authorities. In 
Saudi Arabia, illicit relationships are strictly prohibited. ("Another Filipino," 2011, para. 4)

- The Embassy also appeals to Filipino workers in Saudi Arabia to respect and obey the laws of the Kingdom to avoid inconvenience which might cause someone else's life. ("Another Filipino," 2011, para. 11)

Perhaps also worth noting was the use of the word "inconvenience" in the last excerpt above which, while only mentioned once, was nonetheless disturbing in that it reduced the problem of OFWs on death row to an inconvenience for the government, making a trifling of their predicament and even their lives.

Moreover, the "topoi of burden" hinted at in the passage above ("respect and obey the laws of the Kingdom to avoid inconvenience..." ("Another Filipino," 2011, para.11) became manifest in the one below, where OFWs on death row were regarded as a burden to the country, which has to expend resources to save them despite their "reckless" and "irresponsible" behavior which got them in the situation they were in: "Pagkatapos kung sakaling i-impose sa kanila ang death penalty kargo po ng sambayanang Pilipino ang kanilang problema". "And then if they get imposed with the death penalty, it becomes the burden of the Filipino people"] ("Malacanang warns," 2012, para.5).

Another legitimizing strategy was the use of non sequitur, suggesting that those who were victimized were to be blamed for what happened to them, which is tantamount to blaming rape victims for being raped or murder victims for being murdered. It definitely does not follow. In addition, discourse justified the blaming of OFWs by discrediting their person (argumentum ad hominem). The suggestion was that OFWs ended up being victimized and being on death row because they were ignorant and easily fooled, reckless, and irresponsible.

Metaphors helped in the unflattering construction of OFWs as tanga [stupid] through words such as "victim" "victimized," "falling prey," falling for," "duped" or "nalinlang," "unwitting," "temptation," and "inducements." On the other hand, repeated reminders for OFWs to "protect themselves," "take full responsibility," "be on guard," "remain vigilant and responsible," and "respect," "observe," "obey" and "be aware of laws" (and penalties) suggested OFWs were remiss in these respect. Veloso was even lumped in the company of hardened criminals in one passage: "Veloso has been scheduled to face death by firing squad....along with the infamous "Bali Nine,' an Australian group also caught smuggling heroin into Indonesia" ("President Aquino details," 2015, para. 11)

While discourse represented overseas migrants on death row as victims 
of their own making, the government predictably represented itself as their savior, all-out and relentless in service, and strong in enforcing policies. Repetition and hyperbole were key in this construction. Discourse made liberal use of adverbs and adjectives to exaggerate the extent of government action as seen in these phrases: "all necessary and possible assistance," "exhaust all efforts," "pursuing all avenues," "undertaken all avenues," and "in constant touch."

One article alone ("OFW sentenced to death in Saudi Arabia released, thankful for embassy's relentless work," 2011) contained all of these words: "exerted utmost efforts," "hard work and tireless dedication," "relentless efforts," and "worked relentlessly" (para. 5, 8, 9 \& 11), Another ("DFA extended full assistance to three Filipinos on death penalty for drug trafficking in China," 2011) all of these expressions: "consistent high-level... representations," "constant consular jail visitations," and "full consular assistance" (para.1 \& 5). In addition, the same article actually counted the number of government visitations with OFWs on death row in China. This involved the cases of the three whose executions were upheld by the court. The itemization seems to be a defensive move to show that the government was conscientious in doing its duty:

- Consulate officials visited Ms. Sally eight times during the period of January 2009 to January 2011. (para. 6)

- Consulate officials visited Mr. Ramon eight times also during the period of January 2009 to January 2011. (para. 7)

- Consular officials visited Ms. Elizabeth five times between August 2008 and October 2010. (para. 8)

Perhaps, a hint of condescension could also be detected in the excerpt below, suggesting that the government was already going out of its way to "accommodate" the requests of OFWs on death row and should not be blamed for any delays in the process, which, in this case, it blamed on the family concerned:

[A]rrangements have been made by the Department of Foreign Affairs to accommodate the request of Mary Jane Veloso for her family to visit her in Indonesia. Any delay in their trip is brought about by personal engagements of the family. ("Phl government," 2015, para. 1)

Discourse also sought to deflect blame by stressing that the government had a strong anti-illegal drugs campaign and thus was not 
remiss in protecting overseas migrants. This was achieved through repeated use of the terms "strong" policy, "cooperation," and "enforcement":

- The Aquino administration, which has a strong antiillegal drug policy, is undertaking comprehensive and proactive measures to address the drug mules issue and to protect Filipinos from being victimized by international drug syndicates." ("Malacanang warns," 2012, para. 3)

- The Philippine Government has a strong anti-illegal drug policy, and is closely cooperating with law enforcement agencies in other countries on efforts against anti-drugs trafficking." ("Death sentences," 2011, para. 15)

- The Philippine Government itself has a strong antiillegal drug policy, and is closely cooperating with law enforcement agencies in China and in other countries on efforts against drug trafficking." (Statement of the Department...Guangxi," 2011, para. 13)

- $\quad$ TThe] administration is working towards strengthening the Philippine Drug Enforcement Agency in order to increase the anti-illegal drug agency's ability "to interdict them (drug syndicates). ("Phl to remain," 2011, para.4)

Moreover, disclaimers were used to redirect blame from the government in the event that government efforts to save OFWs on death row failed. There were statements wherein government action came with accompanying caution that Indonesia had the final say on the matter, in effect suggesting that these cases were beyond the Philippine government's control:

- It's important to keep her [alive] to be able to testify against the bigger fish, but that will be subject to [Indonesia's] national interest. ("President Aquino details," 2015, para.14)

- But we continue to exhaust every possible remedy, legal and diplomatic, even as we must accord respect to the legal processes of Indonesia. (Statement of DOJ, 2015, para. 1)

- The government remains hopeful that China will reconsider. But then, we recognize and respect the laws of China on such cases. ("Aquino tells DOJ," 2011, para. 1)

Discourse also resorted to hasty generalization or generalizations 
based on unrepresentative or insufficient observations, as defined by Frans Eeemeren and Rob Grootendorst (1995), and argumentum ad verecundiam (appeal to authority) fallacies to rationalize the cases of overseas migrants on death row, depicting them as random incidents that also happened in other places, even developed countries:

- The Philippines, however, is not the only country facing this problem: Singapore and the United Kingdom have also been in the same situation. ("Palace continues," 2011, para. 4)

- Carandang [noted] that these are isolated cases that happen to other nationalities. ("Government to ask," 2011, para. 10).

In truth, the cases are not random but the consequence of a systemic problem brought about by the Philippine government's continuing failure to provide local opportunities and its long-term dependence on labor export. Moreover, these cases have different contexts, and the fact that other countries, especially developed ones, have had their own nationals on death row overseas at one time or another does not necessarily mean it is all right to simply accept these cases as normal and to dismiss the situation, as lives and futures are at stake. Moreover, discourse rendered insignificant the individual sufferings of overseas migrants on death row by reducing them to statistics or to the number of cases "resolved." For instance, in the article, "DFA: No significant number of Filipinos on death row in China" (2011), below, the government disregarded the conditions of OFWs languishing on death row and instead chose to highlight the number of cases remanded to death penalty with a two-year reprieve, which is the equivalent of life imprisonment and which it considered "resolved." Moreover, the last paragraph revealed that there were actually 73 other similar cases in China but as the lead paragraph indicated, this number was insignificant for the government and, of course, these cases were already considered resolved:

- The Department of Foreign Affairs (DFA) clarifies that there [is] no significant number of Filipinos on death row in China. (para. 1)

- There were originally six death penalty convictions, without reprieves, which reached the Supreme People's Court of China in Beijing. Three of these convictions were eventually affirmed by China's highest court... On the other hand, the penalties in two of the six 
convictions were lowered by the high court from death penalty (without reprieve) to death penalty with twoyear reprieve. (para. 2)

- With five criminal convictions resolved, only one case, which also concerns trafficking of illegal drugs, remains pending review before China's highest court. (para. 5)

- Earlier, 73 Filipinos facing drug trafficking charges in China were saved from death row when they were meted death penalties with two-year reprieves. (para. 6)

Overall, while government discourse overly represented overseas migrants on death row as victims through their own fault and the government as their savior, it was gapingly lacking in context, particularly on government responsibility to protect the rights and welfare of its citizens, whether in the country or abroad. Specific to the cases, only one article ("Aquino tells DOJ, VP to look into cases of OFW drug trafficking," 2011) out of 25 emphasized the government's role in enforcing stricter laws to protect overseas Filipino migrants from drug traffickers and/or illegal recruiters. For once, the government was shown issuing a warning against drug/human traffickers and illegal recruiters instead of cautioning migrants themselves from becoming victimized:

- President Benigno S. Aquino has ordered Vice President Jejomar Binay and Justice Secretary Leila de Lima to look into cases of overseas Filipino workers involved in drug trafficking and find out how and why they managed to leave the country undetected by airport scanners and other technologies. (para. 1)

- Lacierda said the Aquino administration is issuing a stern warning against those using OFWs in their drug trafficking and human trafficking activities. He said the government will go after these individuals and recruitment agencies and make sure they get punished. (para. 9)

Also, since the cases were depicted as isolated incidents and the personal problem of OFWs, the issue of drug/human trafficking was relegated to the sidelines. The nearest that discourse came to recognizing the problem was in the article mentioned above and in the one on Veloso's case below, "President Aquino details last-ditch attempt to save Veloso's life” (2015). Otherwise, as could be seen in previous examples, discourse reduced the issue to simply the number of cases the government was doing something about and to a series of warnings for migrants to guard against being victimized: 
- President Aquino played the "dying person's declaration" card and made a phone call to Indonesian Foreign Affairs Minister Retno Marsudi to propose the idea of turning Veloso into a "primary witness" that could help their government apprehend the 'bigger fish' behind Jakarta's drug problem. (para. 2)

- President Aquino said it is important for the Indonesian government to keep the 30-year old Filipina alive if it is interested in taking down the African drug syndicate that has been trying to penetrate the Indonesian market. (para. 2)

Also noticeably absent in discourse were the reasons and circumstances behind the crimes allegedly committed by overseas migrants on death row, which had the effect of ascribing the guilt to them. It is crucial for the government to understand how and why Filipino migrants get embroiled in these cases for it to be able to work towards addressing the problem. With the exception of Veloso's case, which was given more mileage due to public outcry, in many instances, overseas migrants on death row have been reduced to names, ages, countries, crimes and accompanying sentences. At times, even names were absent, such as in the article, "Death sentences on three Filipinos in China for drug trafficking to be promulgated (2011, para. 6-9), below: The death penalty will be carried out on three Filipino nationals:

1. A male, 42 years old, who was convicted for smuggling 4,113 grams of heroin on 28 December 2008, in Xiamen;

2. A female, 32 years old, who was convicted for smuggling 4,110 grams of heroin on 24 December 2008, in Xiamen;

3. A female, 38 years old, who was convicted for smuggling 6,800 grams of heroin on 24 May 2008, in Shenzhen.

Since the cases of overseas migrants on death row were depicted as brought about by personal problems and "just" isolated incidents involving an insignificant number of overseas migrants, long term or systemic solutions were not part of the discourse. Solutions were at most palliative and consisted of asking for commutations or reprieves, arranging trips for families to visit loved ones on death row abroad, and in the case of the article, "Malacanang addresses issue of 'blood money' for convicted Filipino workers overseas" (2011, para. 11), below, creating technical panels for sourcing and giving blood money to the relatives of the aggrieved: 
Due to appeals for assistance for "blood money" to facilitate the release of an overseas Filipino worker (OFW) who is now on death row in Saudi Arabia, Malacanang announced the creation of a technical working group to find ways to help address his plight as well as other Filipinos on death row abroad (para.1).

\section{Conclusion}

In keeping with the ideological principles reiterated by van Djik (2000), dominant discourse on overseas migrants on death row was overwhelmingly favorable toward the government (the ingroup), tending to highlight positive aspects and legitimize or ignore negative aspects of the case. Conversely, discourse was highly unfavorable towards overseas Filipino migrants (the outgroup), tending to highlight negative aspects and virtually ignoring positive aspects of the case. To legitimize and justify its representation, the government used an armament of discursive strategies consisting of the topoi of choice and burden; non sequitur, ad hominem, ad verecundiam, and hasty generalization fallacies; and metaphors, repetition, hyperbole, and disclaimers.

Overall, discourse hews close to the bagong bayani [modern hero] construction of labor migration as a heroic sacrifice for the family but with emphasis on the dimension of personal choice and responsibility. Specifically, government discourse represented overseas migrants on death row as victims who were to be blamed for their own situation, in effect constructing the problem as the migrants' personal responsibility and deflecting blame away from the government and its failure to provide for the welfare and protection of its people. Related to this, migrants were constructed as a burden since the government still had to expend resources to save them, despite their alleged recklessness, foolishness, or irresponsibility landing them on death row. As a result, the government was represented extremely favorably: as a savior, all-out and relentless in its efforts to save migrants and strong in terms of its drug/human trafficking policies. Discourse also constructed the cases as isolated, random and insignificant in number, and court decisions in other countries beyond government control, thus helping the government evade culpability.

As cases of overseas migrants on death row have become increasingly part of the labor migration firmament in recent years, the results are troubling. An initial step towards finding a solution would be to recognize these cases as part of the bigger human and drug trafficking problem-a government problem. Migrant groups and advocates have been urging the government to implement a stronger information campaign about human 
and drug trafficking for OFWs, taking the stance that while "prevention is the best protection, empowerment is the [next] best way for migrants to protect themselves and improve their condition" (CMA 2012, p. 63.). Unless the government starts being serious about the human and drug trafficking problem, the Philippines will continue to be a "country of Mary Janes."

Findings from this study suggest that the media should take a more critical stance in using official press statements and releases and seek to broaden discourse by incorporating the views of migrants, migrant groups, and advocates. This would help audiences to better understand labor migration and drug or human trafficking issues and make them more likely to demand accountability from those in power. For sure, this is a challenge in the highly competitive and fast-paced media landscape. But it is a challenge the media must take if they want to be true to their hallowed mandate, as famously quoted by American journalist Finley Peter Dunne, "to comfort the afflicted and afflict the comfortable" (Shedden, 2014, para. 5). 


\section{References}

2015 CFO Statistics on Philippine International Migration. (June 2017). Commission on Filipinos Overseas. Retrieved from http://www.cfo.gov.ph/images/pdf/2017/2015compendiumstats-insidepages2017-06-29.pdf.

Another Filipino detainee in Riyadh, Saudi Arabia saved from death penalty. (2011, June 13). Retrieved from http://www.officialgazette.gov.ph/2011/06/13/another-filipino-detainee-in-riyadh-saudiarabia-saved-from-death-penalty/.

Aquino tells DOJ, VP to look into cases of OFW drug trafficking. (2011, March 29). Retrieved from http:// www.philippinecentersf.com/news/1472/575/Lady-Legislators-call-on-Aquino-in-Malacanang/ d,phildet/.

Baubion, C. (2013). OECD risk management:Strategic crisis management. Retrieved fromwww.mmc.com/ content/dam/mmc-web/Files/Strategic-Crisis-Management-paper-July-2013.pdf.

Carbonero, G. (2013). Spanish political discourse on immigration in time of crisis. In Lirola, M. (Ed.), Discourses on immigration in times of economic crisis, 260-286. Cambridge: Cambridge Scholars Publishers. Retrieved from http://academia.edu/7831395/Discourses_of_Immigration_in_Times_ of_Economic_Crisis_A_Critical_Perspective.

Center for Migrant Advocacy. (2012). Migration and development: Protecting the OFWs and changing the migration status quo for development. Center for Migrant Advocacy. Retrieved from https:// centerformigrantadvocacy.files.wordpress.com/2012/06/rtd-book.pdf.

Death sentence of 2 Filipinos in China commuted to life imprisonment; DFA reiterates call against "drug mule" ops. (2011, July 12). Retrieved fromhttp://www.officialgazette.gov.ph/2011/07/12/deathsentence-of-2-filipinos-in-china-commuted-to-life-imprisonment-dfa-reiterates-call-against-drugmule-ops/.

Death sentences on three Filipinos in China for drug trafficking to be promulgated. (2011, February 15). Retrieved from http://www.officialgazette.gov.ph/2011/02/15/death-sentences-on-three-filipinosin-china-for-drug-trafficking-to-be-promulgated/.

DFA extended full assistance to three Filipinos on death penalty for drug trafficking in China. (2011, February 18). Retrieved from http://www.officialgazette.gov.ph/2011/02/18/dfa-extended-fullassistance-to-three-filipinos-on-death-penalty-for-drug-trafficking-in-china-2/.

DFA: No significant number of Filipinos on death row in China. (2011, March 31). Retrieved from http:// www.officialgazette.gov.ph/2011/03/31/dfa-no-significant-number-of-filipinos-on-death-row-inchina/.

Encinas-Franco, J. (2011). The politics of language in labor export: A historical analysis of the "Bagong Bayani" and overseas employment policies (Unpublished doctoral dissertation). University of the Philippines, Diliman.

Entman, R. (1993). Framing: Toward clarification of a fractured paradigm. Journal of Communication, 43 (4), 51-69. Retrieved from https://www.unc.edu/ fbaum/teaching/articles/J-Communication-1993Entman.pdf.

Esmaquel II, P. (2015, May 6). 92 migrant Filipinos on death row; 3,800 jailed. Rappler. Retrieved from http://www.rappler.com/nation/92275-filipinos-deatstatistics. 
Filipina convicted for drug-smuggling in Guangzhou. (2011, July 2). Retrieved from http://www. officialgazette.gov.ph/2011/07/02/filipina-convicted-for-drug-smuggling-in-guangzhou/.

Ford, M., Lyons, L., \& van Schendel W. (2012). Labour migration and human trafficking: Critical perspectives from Southeast Asia. London: Routledge.

Gabriela pushes probe of DFA inaction into plight of Mary Jane, other jailed OFWs. (2015, May 1). Gabriela Women's Party. Retrieved from http://www.gabrielawomensparty.net/content/gabriela-pushesprobe-dfa-inaction-plight-mary-jane-other-jailed-ofws.

Gorgonio, L. (2007, Aug 3). Lack of enforcement mechanism blamed for OFW trafficking to Iraq. GMA News Online. Retrieved from http://www.gmanetwork.com/news/news/content/54209/lack-ofenforcement-mechanism-blamed-for-ofw-trafficking-to-iraq/story/.

Government to ask China for commutation of sentence of Filipinos facing death penalty (2011, April 1). Retrieved from http://piadispatch.blogspot.com/2011/04/pia-dispatch-friday-april-1-2011.html.

Ibon Foundation. (2015, April 29). Mary Jane Veloso case mirrors mounting govt neglect of OFWs; govt budget for OFWs falling. Migrante-NL. Retrieved from http://www.migrante.nl/2015/04/29/maryjane-veloso-case-mirrors-mounting-govt-neglect-of-ofws-govt-budget-for-ofws-falling/.

Igor, P. (2011).The critical analysis of style:The case of press releases (Unpublished diploma thesis). University of Vienna, Austria. Retrieved from https://core.ac.uk/download/pdf/11593546.pdf

International Organization for Migration. (2013). Country Migration Report: The Philippines. Retrieved from https://www.iom.int/files/live/sites/iom/files/Country/docs/CMReport-Philipines-2013.pdf

lyengar, S. (1990, March). Framing responsibility for social issues: The case of poverty. olitical Behavior, 12 (1), 19-40. Retrieved from http://www.jstor.org/stable/586283?seq=1\#page_scan_tab_contents.

lyengar, S., \& Simon, A. (1993, June 1). News coverage of the Gulf crisis and public opinion. Sage Journals, 20(3), 365-383. doi10.1177/009365093020003002.

Jacobs, G. (1999). Preformulating the news: An analysis of the metapragmatics of press releases [Book catalogue]. Retrieved from https://benjamins.com/\#catalog/books/pbns.60/main.

Katumbas ng halos P66,000, magiging buwanang sahod ng mga DH sa Japan. (2005, November 23). 24Oras [Video file]. Retrieved from https://youtu.be/ktliTBwxlkk.

Lirola, M. (2013) (Ed.), Discourses on immigration in times of economic crisis. Retrieved from academia. edu/7831395/Discourses_of_Immigration_in_Times_of_Economic_Crisis_A_Critical_Perspective. Malacanang addresses issue of 'blood money' for convicted Filipino workers overseas. (2011, July21). Retrieved from http://www.philippineembassy-usa.org/news/1983/619/Palace-launchespublication-on-priority-legislative-measures-of-President-Aquino/.

Malacanang warns overseas Filipino workers from working as drug mules to avoid death penalty. (2012, February 13). Retrieved from http://oslope.dfa.gov.ph/2012/210-malacanang-warns-overseasfilipino-workers-from-working-as-drug-mules-to-avoid-death-penalty.

Mary Jane Veloso spared from execution. (2015, April 29). GMA News Online. Retrieved from http://www. gmanetwork.com/news/news/nation/478106/mary-jane-veloso-spared-from-execution/story/.

Office of the United Nations High Commissioner for Human Rights .(2012). Principles and guidelines for a human rights approach to poverty reduction strategies. OHCHR. Retrieved from http://www.ohchr. org/Documents/Publications/PovertyStrategiesen.pdf. 
OFW sentenced to death in Saudi Arabia released, thankful for embassy's relentless work. (2011, April 18).

Retrieved from http://www.officialgazette.gov.ph/2011/04/18/ofw-sentenced-to-death-in-saudiarabia-released-thankful-for-embassy\%E2\%80\%99s-relentless-work/.

Palace continues to exhaust all efforts to save Filipinos on China death row. (2011, February 18).Retrieved from http://www.officialgazette.gov.ph/2011/02/18/valte-palace-continues-to-exhaust-all-effortsto-save-filipinos-on-china-death-row/.

PHL government ready to assist Mary Jane Veloso's family for another visit. (2015, April 22). Retrieved from https://dfa.gov.ph/newsroom/dfa-releasesupdate/5998-phl-government-ready-to-assistmary-jane-veloso-s-family-for-another-visit.

PHL to remain relentless in fight against drugs - Aquino. (2011, December 1). Retrieved from http:// piadispatch.blogspot.com/2011/12/pia-news-dispatch-friday-december-1.html.

Piocos, C. (2015). Suffering that counts. The Politics of Sacrifice in Filipina Labor Migration [Abstract]. Retrieved from http://dlsu.academia.edu/CarlosPiocos/Journal-Articles.

President Aquino details last-ditch attempt to save Veloso's life. (2015, April 28). Retrieved from https:// pcoo.gov.ph/april-28-2015-news-releases/.

Press statements and press releases. (2012). Ace Electoral Knowledge Network. Retrieved from http:// aceproject.org/ace-en/topics/me/onePage.

Resolution urging an inquiry and assessment on the status of Filipinos on death row. (Senate Resolution 421). (2008, May 27). Retrieved from https://www.senate.gov.ph/lis/bill_res. asp $x$ ? congress $=14 \& \mathrm{q}=\mathrm{SRN}-421$.

Sen, A. (1999). Development as freedom. Retrieved from http://www.c3l.uni-oldenburg.de/cde/OMDE625/ Sen/Sen-intro.pdf.

Shedden, D. (2014, October 7).Today in media history:Mr.Dooley:'The job of the newspaper is to comfort the afflicted and afflict the comfortable'. Poynter. Retrieved from https://www.poynter.org/news/ today-media-history-mr-dooley-job-newspaper-comfort-afflicted-and-afflict-comfortable.

Sleurs, K., Jacobs, G., and Van Waes, L. (2002). Constructing press release: Quotations as preformulation https://ideas.repec.org/p/ant/wpaper/2002017.html.

Souders, M. C., \& Dillard, K. N. (2014). Framing connections: Essay on improving therelationship between rhetorical and social science frame studies, including a study on Bush's framing of immigration. International Journal of Communication, 8, 1008-1028. Retrieved from http://ijoc.org/index.php/ ijoc/article/download/1467/1114.

Statement of DOJ Undersecretary Francisco F. Baraan on the case of Mary Jane Veloso. (2015, April 17). Retrieved from http://www.officialgazette.gov.ph/2015/04/17/statement-doj-undersecretary-onthe-case-of-mary-jane-veloso/.

Statement of the Department of Foreign Affairs on the death penalty case of a Filipino in Guangxi. (2011, November 30). Retrieved from http://www.officialgazette.gov.ph/2011/11/30/statement-of-thedepartment-of-foreign-affairs-on-the-death-penalty-case-of-a-filipino-in-guangxi-november-30$2011 \%$

Statement of the Department of Foreign Affairs on the death penalty case of OFW Carlito Lana. (2014, December 13). Retrieved from https://dfa.gov.ph/dfa-news/dfa-releasesupdate/4923-statementof-the-department-of-foreign-affairs-on-the-death-penalty-case-of-ofw-carlito-lana. 
Teodoro, L. (2015, April 24). Not all cases of OFWs on death row are equal. BussinessWorld Online. Retrieved from http://www.bworldonline.com/content.php?section=Opinion\&title=not-all-cases-of-ofwson-death-row-are-equal\&id=106726.

Van Dijk, T. (2000). The reality of racism: On analyzing parliamentary debates on immigration. In G. Zurstiege (Ed.), Festschrift für die Wirklichkei, 211-226. Retrieved from http://www.discourses.org/ OldArticles/The\%20reality\%20of\%20racism.pdf.

Van Eemeren, F., \& Grootendorst, R. (1995). Argumentum ad hominem: A pragma-dialectical case in point. In H. Hansen \& R. Pinto (Eds.), Fallacies:Classical and contemporary readings (pp. 130-144). Retrieved from http://www.ditext.com/eemeren/aah.html.

Varona, K.Y.(2010). The framing of the front-page coverage of the 2004 Angelo de laCruz case in the Philippine Daily Inquirer and the Philippine Star (Unpublished master's thesis). University of the Philippines, Diliman.

Wallack, L., Dorfman, R., Jernigan, D., \& Themba-Nixon, M. (1993). Media advocacy and public health: Power for prevention. Newbury Park, California: Sage.

Wodak, R. (2008). Critical discourse analysis: History, agenda, theory and methodology. In R. Wodak \& M. Meyer (Eds.). Methods for critical discourse analysis (pp. 1-33). Retrieved from http://didattica. uniroma2.it/files/scarica/insegnamento/164608-Lingua-Inglese-2-Mod.-A/36840-Wodak-Meyer2016-Methods-of-Critical-Discourse-Studies-pp.-1-13.

Zarefsky, D (2004). Presidential rhetoric and the power of definition. Presidential Studies Quaterly, 34 (3), 607-619. Retrieved from http://chantrill.net/Zarefsky_Presidential_Definition.pdf

KAREN Y. VARONA is a Ph.D. in Communication candidate at the University of the Philippines Diliman, where she also earned her M.A. in Media Studies (Journalism). An Assistant Professor at the University of the Philippines Visayas (Miagao), she has published on the role of internet memes in public discourse and on media coverage of Overseas Filipino Workers. (Corresponding author:varonaky@yahoo.com) 